\title{
Primary syphilis: a histological and immunohistochemical evaluation
}

\author{
Ling Leng \\ Peking University People's Hospital \\ Hui Zi Gong \\ Peking Union Medical College Hospital \\ Tao Wang \\ Peking Union Medical College Hospital \\ He Yi Zheng \\ Peking Union Medical College Hospital \\ Jun Li ( $\square$ lijun35@hotmail.com ) \\ Peking Union Medical College Hospital https://orcid.org/0000-0003-4820-5251
}

\section{Research article}

Keywords: Primary syphilis, Histological features, Immunohistochemistry, Treponema pallidum

Posted Date: February 28th, 2020

DOl: https://doi.org/10.21203/rs.2.24783/v1

License: (c) (i) This work is licensed under a Creative Commons Attribution 4.0 International License. Read Full License 


\section{Abstract}

Background: Syphilitic chancre could be misdiagnosed as other skin diseases and a biopsy is sometimes done before serological testing, which makes it essential to find possible primary syphilis patients through histopathology and immunohistochemistry (IHC).

Method: We sought to determine the histopathological and IHC characteristics in primary syphilis. Eleven biopsy specimens were collected from 9 patients diagnosed with primary syphilis. Specimens were analyzed for T. pallidum using antibody to T. pallidum. We also compared IHC results with the histological characteristics.

Results: In our study, plasma cells infiltration was the most common pattern [90.9\% (10/11)] in primary syphilis. Necrotic keratinocytes could be observed in 54.5\% (6/11) of primary syphilis. T. pallidum was discovered in 9 of 10 (90.0\%) primary syphilis by IHC. T. pallidum is mainly detected in the medium to superficial dermis and the lower epidermis regions. In the dermis area, T. pallidum was discovered mainly around the perivascular regions.

Conclusion: Although serological tests remain the gold standard for the confirming diagnosis of syphilis infection, Histopathological and IHC could be helpful in the diagnosis of some syphilitic patients when serologic testing is not capable of detecting T. pallidum antibodies in serum. Using IHC technique allows us to precisely find out the location of the microorganism in the syphilitic skin lesions.

\section{Background}

Syphilis is a multistage sexually transmitted disease (STD) due to Treponema pallidum subsp pallidum (T. pallidum). Syphilis remains a major health problem throughout the world and can cause genital ulceration that may enhance the risk of transmission and acquisition of human immunodeficiency virus (HIV). Vertical transmission of T. pallidum could cause congenital syphilis. In China, syphilis has increased dramatically during the last three decades, and the average annual increase in the incidence of syphilis has been as high as $16.3 \%{ }^{1}$ According to infectious course, syphilis can be divided into three main stages: primary, secondary, and tertiary. If untreated, about $1 / 3$ primary syphilitic cases will progress to secondary syphilis.

Diagnosis of syphilis during the primary stage is particularly important, since appropriate treatment can prevent the development of secondary stage and chronic disease stage. T. pallidum is usually identified by dark field microscopy and by serologic test. However, false negative or false positive result of microscopy testing often occurs when laboratory staffs lack of experiences to distinguish T. pallidum from other bacteria. Serologic test for syphilis involves serological assays based on nontreponemal antibody [Serologic tests for syphilis reveal the individual's immunologic status, but not whether the patient is currently infected. Because these tests use lipoidal antigens rather than T. palliduin or components of it, they are called nontreponemal ailtigen tests. Most widely used are Venereal Disease Research Laboratory or rapid plasma regain (RPR)] and treponemal antibody [fluorescent treponemal antibody absorption (FTA-ABS) or T. pallidum particle agglutination (TPPA)/T. pallidum hemagglutination assay (TPHA)] responses. Serological testing for syphilis is now recognized as reliable methods for confirmation of the diagnosis and the reliable methods to evaluate the preliminary efficacy of the treatment. However, the results of serologic tests for syphilis are only positive in $50 \%$ (nontreponemal tests) to $90 \%$ (treponemal tests) of patients with primary syphilis. The likelihood of positivity depends on the duration of infection. Furthermore, false negative serological testing result has been reported previously in early syphilis/HIV co-infection or in prezone phenomenon (Patients with very high antibody titers, as occur in secondary syphilis, may have a false negative result when undiluted serum is tested. This prozone phenomenon will be overcome by diluting the serum).

Primary syphilitic chancre could be misdiagnosed as other skin diseases and a skin biopsy is sometimes done before serum testing, which makes it essential to dignosis atypical syphilis cases through skin histopathology. However, histopathological features (such as plasma cells) sometimes may be sparse and even absent, and silver stain, such as the Warthin Starry, or Levaditi methods is often negative (T. pallidum are usually found by the silver stain method. However, silver stain method is characterized by obvious background artifacts). Silver staining could discover spirochetes, but it is nonspecific to T. pallidum. Warthin Starry (silver stain method) may be hard to discover skin lesions in non-treponemal spirochete contaminated locations. We need to find a better method to detect spirochete in tissue. IHC directed anti-T. pallidum antibodies achieves significantly improved overall specificity and sensitivity. ${ }^{2,3}$ In our study, a polyclonal antibody to T. pallidum was used to directly and specifically detect T. pallidum in skin lesions from patients with primary syphilis and we also compared $\mathrm{IHC}$ results with histological features.

\section{Methods}

Using our written and electronic medical records, 11 skin biopsy tissue specimen from 9 cases diagnosed with primary syphilis according to clinical presentation, serological testing results and follow-up serological testing results between 2008 and 2018 were obtained from the STD Center of Peking Union Medical College Hospital, China. All methods were carried out in accordance with the relevant guidelines and regulations. Written informed consent was obtained from all participantsThis study was approved by the institutional review boards of the Peking Union Medical College Hospital (reference number S-K653).

Primary syphilis was defined by the presence of genital ulcers and/or inguinal lymphadenopathy, confirmed to be positive for T. pallidum in clinical specimens by RPR and TPHA/TPPA, and/or FTA-ABS. Once the diagnosis was confirmed, three doses of penicillin G benzathine, 2.4-MU intramuscular each, separated by one week was given to the patient. The clinical data including the patient's age, sex, skin lesions, HIV status, syphilis serological testing results, treatment and follow-up results were obtained from the medical record. 
The hematoxylin and eosin staining sections were reviewed and the histopathological diagnoses confirmed. A panel of histopathological features was evaluated blindly by two certified dermatologists, both of them were fully trained in dermatopathology. The cases were classified as lacking or having the following histological features: plasma cells (Fig. 1. A); endothelial swelling (Fig. 1. B); interstitial patterns of inflammation; elongated rete ridges; irregular acanthosis; vacuolar pattern of inflammation; lymphocytes with ample cytoplasm; neutrophils in the stratum corneum; lichenoid pattern of inflammation; keratinocyte apoptosis (Fig. 1. C and D).

Formalin-fixed paraffin-embedded tissues were sliced into 4-micrometer thick sections. To detect T. pallidum, the avidin biotin peroxidase complex technique was used. After heat induced epitope retrieval and primary rabbit polyclonal antibody directed to T. pallidum (Novus Biologicals, Inc., CA, USA). For comparison, 3 cases that were negative for syphilitic serum testing but histological manifestations were similar to primary syphilis were included: two case of balanitis, one case of lichen sclerosus et atrophicus.

\section{Results}

Clinical and IHC results of the 10 specimens are summarized in Table 1. The histologic features of the 11 sections are summarized in Table 2 . All the patients also had clinical pictures. One patient had biopsies done at 2 different anatomical sites (Cases 5 and 6 ). One patient had skin biopsies done at different times [Cases 9 and 10 (two weeks later)]. The female to male ratio was 3:6. The age of the patients ranged from 19 to 58 years. All patients were negative for HIV virus. One patient (Cases 5 and 6 ) also had secondary syphilis at the same time. Three patients (Cases $1,9 / 10$, and 11$)$ also tested positive to FTA-ABS-IgM. All patients exhibited sero-reversion within 12 months after treatment (Table 3 ). 
Table 1

Clinical features and detection of T. pallidum in primary syphilis cases

\begin{tabular}{|c|c|c|c|c|c|c|c|c|c|}
\hline Case & Age & $\begin{array}{l}\text { Prebiopsy } \\
\text { differential }\end{array}$ & $\mathrm{IHC} \Leftarrow$ & Localization‡ & $\begin{array}{l}\text { Biopsy } \\
\text { location }\end{array}$ & $\begin{array}{l}\text { Skin lesion } \\
\text { location }\end{array}$ & Skin Lesion & Durationq & No.t \\
\hline 1 & $\begin{array}{l}35- \\
40\end{array}$ & Ulcer & Dense & $\begin{array}{l}\text { Lower epidermis, dermo- } \\
\text { epidermal, dermis (mainly } \\
\text { perivascular) areas }\end{array}$ & $\begin{array}{l}\text { Coronary } \\
\text { sulcus }\end{array}$ & Glans & Ulcer & 3 & 1 \\
\hline 2 & $\begin{array}{l}55- \\
60\end{array}$ & $\begin{array}{l}\text { Extramammary } \\
\text { Paget's disease }\end{array}$ & Dense & $\begin{array}{l}\text { Median and deep dermis, } \\
\text { perivascular areas }\end{array}$ & Penis & $\begin{array}{l}\text { Root of the } \\
\text { penis }\end{array}$ & Ulcer & 6 & 1 \\
\hline 3 & $\begin{array}{l}30- \\
35\end{array}$ & $\begin{array}{l}\text { Mammary } \\
\text { Paget's disease }\end{array}$ & Sparse & Lower epidermis & $\begin{array}{l}\text { Left } \\
\text { nipple }\end{array}$ & Left nipple & $\begin{array}{l}\text { Scaly } \\
\text { erythema }\end{array}$ & 12 & 1 \\
\hline 4 & $\begin{array}{l}45- \\
50\end{array}$ & $\begin{array}{l}\text { Extramammary } \\
\text { Paget's disease }\end{array}$ & Moderate & $\begin{array}{l}\text { Lower epidermis, dermo- } \\
\text { epidermal and upper dermis } \\
\text { areas }\end{array}$ & Penis & Penis & $\begin{array}{l}\text { Erythema } \\
\text { and ulcer }\end{array}$ & 8 & 1 \\
\hline 5 & $\begin{array}{l}15- \\
20\end{array}$ & $\begin{array}{l}\text { Mammary } \\
\text { Paget's disease }\end{array}$ & Dense & $\begin{array}{l}\text { Lower epidermis, dermo- } \\
\text { epidermal, dermis (mainly } \\
\text { perivascular) areas }\end{array}$ & $\begin{array}{l}\text { Left } \\
\text { nipple }\end{array}$ & $\begin{array}{l}\text { Bilateral } \\
\text { nipples }\end{array}$ & $\begin{array}{l}\text { Erythema } \\
\text { and erosion }\end{array}$ & 8 & 2 \\
\hline 6 & $\begin{array}{l}15- \\
20\end{array}$ & $\begin{array}{l}\text { Mammary } \\
\text { Paget's disease }\end{array}$ & Dense & $\begin{array}{l}\text { Lower epidermis, dermo- } \\
\text { epidermal, dermis (mainly } \\
\text { perivascular) areas }\end{array}$ & $\begin{array}{l}\text { Right } \\
\text { nipple }\end{array}$ & $\begin{array}{l}\text { Bilateral } \\
\text { nipples }\end{array}$ & $\begin{array}{l}\text { Erythema } \\
\text { and erosion }\end{array}$ & 8 & 2 \\
\hline 7 & $\begin{array}{l}35- \\
40\end{array}$ & Ulcer & Moderate & $\begin{array}{l}\text { Dermo-epidermal, perivascular } \\
\text { (upper dermis) areas }\end{array}$ & Glans & $\begin{array}{l}\text { Glans and } \\
\text { right } \\
\text { scrotum }\end{array}$ & Ulcer & 2 & 2 \\
\hline 8 & $\begin{array}{l}55- \\
60\end{array}$ & Behcet's disease & Moderate & $\begin{array}{l}\text { Lower epidermis, dermo- } \\
\text { epidermal and upper dermis } \\
\text { areas }\end{array}$ & Penis & $\begin{array}{l}\text { Penis and } \\
\text { scrotum }\end{array}$ & Ulcer & 16 & 3 \\
\hline 9 & $\begin{array}{l}40- \\
45\end{array}$ & Eczema & Dense & $\begin{array}{l}\text { Dermo-epidermal, dermis (mainly } \\
\text { perivascular) areas }\end{array}$ & $\begin{array}{l}\text { Left } \\
\text { nipple }\end{array}$ & Left nipple & $\begin{array}{l}\text { Erythema, } \\
\text { erosion and } \\
\text { crust }\end{array}$ & 2 & 1 \\
\hline 10 & $\begin{array}{l}40- \\
45\end{array}$ & Eczema & Negative & Negative & $\begin{array}{l}\text { Left } \\
\text { nipple }\end{array}$ & Left nipple & $\begin{array}{l}\text { Erythema, } \\
\text { erosion and } \\
\text { crust }\end{array}$ & 4 & 1 \\
\hline 11 & $\begin{array}{l}35- \\
40\end{array}$ & Scabies & NA & NA & Penis & $\begin{array}{l}\text { Root of the } \\
\text { penis }\end{array}$ & Nodules & 12 & 2 \\
\hline \multicolumn{10}{|c|}{$\begin{array}{l}\text { EImmunohistochemistry, Bacteria were detected by using polyclonal antibody directed against T. pallidum in parraffin-embedded biopsy samples by } \\
\text { IHC technique as described in Methods. A representative recognition pattern of T. pallidum is presented in Figures. }\end{array}$} \\
\hline \multicolumn{10}{|c|}{ ‡ Spirochete immunostain location. A representative recognition pattern of T. pallidum is presented in Figures. } \\
\hline \multicolumn{10}{|c|}{ 9 Primary syphilitic lesions lasted for weeks. } \\
\hline \multicolumn{10}{|c|}{ † Number of Chancres. } \\
\hline
\end{tabular}


Table 2

Histological features of the 11 sections

\begin{tabular}{|c|c|c|c|c|c|c|c|c|c|c|}
\hline Case & $\begin{array}{l}\text { Plasma } \\
\text { cells }\end{array}$ & $\begin{array}{l}\text { Endothelial } \\
\text { swelling }\end{array}$ & $\begin{array}{l}\text { Interstitial } \\
\text { inflammation }\end{array}$ & $\begin{array}{l}\text { Irregular } \\
\text { acanthosis }\end{array}$ & $\begin{array}{l}\text { Elongated } \\
\text { rete } \\
\text { ridges }\end{array}$ & $\begin{array}{l}\text { Vacuolar } \\
\text { pattern }\end{array}$ & $\begin{array}{l}\text { Lymphocytes } \\
\text { with ample } \\
\text { cytoplasm }\end{array}$ & $\begin{array}{l}\text { Neutrophils } \\
\text { in stratum } \\
\text { comeum }\end{array}$ & $\begin{array}{l}\text { Lichenoid } \\
\text { pattem }\end{array}$ & $\begin{array}{l}\text { Necrotic } \\
\text { keratinocytes }\end{array}$ \\
\hline 1 & + & + & - & - & - & + & + & + & + & - \\
\hline 2 & - & - & + & - & - & - & + & + & - & - \\
\hline 3 & + & + & + & + & + & + & + & + & + & + \\
\hline 4 & + & + & - & + & + & + & + & + & + & + \\
\hline 5 & + & + & + & + & + & + & + & + & - & + \\
\hline 6 & + & + & + & + & + & + & + & + & - & + \\
\hline 7 & + & + & + & - & - & + & + & - & + & - \\
\hline 8 & + & + & - & + & + & + & + & + & + & + \\
\hline 9 & + & + & + & + & + & + & + & + & + & + \\
\hline 10 & + & + & + & - & - & - & + & + & - & - \\
\hline 11 & + & + & + & - & - & - & + & - & - & - \\
\hline
\end{tabular}

Table 3

Follow-up results after treatment

\begin{tabular}{|llllllll|}
\hline Case & RPR Titer & HIV & TPPATPHA & FTA-ABS-IgG & FTA-ABS-IgM & Follow-up & Monthsq \\
\hline 1 & 0 & N & P & P & P & Lost & \\
\hline 2 & $1: 8$ & N & P & - & - & Cured & 4 \\
\hline 3 & $\geq 1: 32$ & N & P & - & - & Cured & 12 \\
\hline 4 & $\geq 1: 32$ & N & P & - & - & Cured & 12 \\
\hline 5 & $\geq 1: 32$ & N & P & - & - & Cured & 9 \\
\hline 6 & $\geq 1: 32$ & N & P & - & - & Cured & 9 \\
7 & $1: 1$ & N & P & - & - & Lost & \\
\hline 8 & $\geq 1: 32$ & N & P & - & - & Cured & 6 \\
\hline 9 & $1: 8$ & N & P & P & P & Cured & 6 \\
\hline 10 & $1: 8$ & N & P & P & P & Cured & 6 \\
\hline 11 & 0 & N & P & P & P & Cured & 5 \\
\hline 9 sero-reversion time; N, negative; P, positive & & & \\
\hline
\end{tabular}

Eleven biopsies with primary syphilis were included in the histologic analysis. In primary syphilis, plasma cells infiltration [90.9\% (10/11)] was the most common pathologic characteristics (Table 2 and Fig. 1. A). We also noted that necrotic keratinocytes could be observed in $54.5 \%(6 / 11)$ primary syphilis cases (Table 2 and Fig. 1. C and D). The specimens analyzed by IHC were shown in Table 1. Micro-organisms were discovered in 9 of 10 ( $90.0 \%$ ) specimens from cases with primary syphilis and were not detected in the control sections. T. pallidum were seen in all positive patients as typical spiral and thread-like organisms highlighted by red chromogen. The micro-organism is mainly detected in the medium to superficial dermis and the lower epidermis regions (Fig. 2, A). In the dermis area, the micro-organism was discovered mainly in the perivascular region (Fig. 2, B). The quantity of the bacteria varied with only a few T. pallidum (sparse, Fig. 2, C), a moderate amount (moderate) and a large amount (dense, Fig. 2, D).

\section{Discussion}

Clinically, primary syphilis can present as other ulcerative dermatosis. Histologically, the same applies. In our study, plasma cells infiltration (90.9\%) was the most common pattern. It is appear that plasma cells play an important role in the pathophysiology of primary syphilis. Further research could include IHC stain of CD138/38, so as to detect the plasma cells neglected in hematoxylin and eosin staining sections. Necrotic keratinocytes could be detected in $54.5 \%$ of primary syphilis patients. Similarly, previous studies also showed that ulcerative lesions covered by necrotic material and cellular debris were 
most observed in primary syphilis. ${ }^{4-5}$ Dilated blood vessels with swelling endothelial cells is generally considered to be a phenomenon of early syphilis. ${ }^{6}$ These findings are explained with the IHC findings that T. pallidum was discovered mainly in the perivascular and vascular region in the dermis area. Our study result is in accordance with the previous animal experiment which find T. pallidum localizing to vascular and perivascular regions in all the courses of infection in the infected rabbit testicular tissue samples. ${ }^{7}$ According to literature report, T. pallidum is attachment to the endothelial lining of blood vessels, migration of T. pallidum between the junctions of vascular endothelium cells. ${ }^{8,9}$.

In our study, we have found that the micro-organism is mainly detected in the dermo-epidermal areas in epidermis and lower part of epidermis. In the dermis, the micro-organism was detected mainly in the medium and superficial perivascular region where a notable inflammatory response was in place. Up to now, there is still no reasonable explanation for upper dermal and the epidermal distribution of the micro-organism where it should be killed by our immune system. Previous study showed that early stage syphilitic skin lesions have a characteristic increased T-suppressor lymphocytes acting as closing a innate immune response and causing the persistence of the micro-organism in these lesions. ${ }^{10}$ The other possible reason is that the T. pallidum adhesin Tp0751 was previously shown to bind laminin, the most abundant component of the basement membrane, ${ }^{11}$ suggesting T. pallidum in host tissue colonization. ${ }^{12-14}$

\section{Conclusion}

The usual technique for detecting T. pallidum in tissue samples is through Warthin-Starry (silver staining method). Obvious background artifacts are common, as the Warthin-Starry highlights melanin granules also and reticulin fibers causing it difficult to detect the T. pallidum. Our study focused on the evaluation of T. pallidum in primary syphilis by $\mathrm{IHC}$ and compared $\mathrm{IHC}$ with histologic features. We discovered the presence of $\mathrm{T}$. pallidum in $90.0 \%$ of primary syphilitic patients. It is still unknown what proportion of primary syphilis escape this testing method. The capability of T. pallidum escaping our immune system is largely unknown and the distribution of T. pallidum in the lesion could bring us some clues to figure out its pathogenesis.

\section{Declarations}

Ethical Approval and Consent to participate: This study was approved by the institutional review boards of the Peking Union Medical College Hospital (reference number S-K653). All patients consent to participate in this study.

Consent for publication: Written consent for publication have obtained from patients. Informed consent was obtained from all subjects.

Availability of data and materials: The datasets used and/or analysed during the current study are available from the corresponding author on reasonable request.

Competing interests: None reported.

Funding/Support: Supported by Beijing Municipal Science and Technology Commission No. Z191100006619011. We declare that we have no conflicts of interest. We declare that the paper has not been submitted to another journal, and has not been published in whole or in part elsewhere previously.

Authors' contributions: Dr Jun Li and Dr He Yi Zheng had full access to all data in the study and take responsibility for the integrity of data and accuracy of data analysis, as well as for the study concept and design. All the authors take responsibility for acquisition, analysis, and interpretation of the data. Ling Leng takes responsibility for drafting of the manuscript. Drs Tao Wang, and Hui Zi Gong take responsibility for critical revision of the manuscript for important intellectual content. Ling Leng was responsible for technical support.

Acknowledgements: We thank the colleagues in the Department of dermatology, Peking Union Medical College Hospital for partially supporting this study and also the general patients included in the study.

Authors: Ling Leng, * Hui Zi Gong*, MD, Tao Wang, MD, He Yi Zheng, MD, Jun Li, MD

${ }^{*}$ co-first authors

Author Affiliations: Department of Medical Science Research Center (Ling Leng), Department of Dermatology (H Z Gong, T Wang, H Y Zheng, J Li), Peking Union Medical College Hospital, Chinese Academy of Medical Sciences and Peking Union Medical College, Beijing, China, 100730

Correspondence to: Dr Jun Li, Department of Dermatology, Peking Union Medical College Hospital, Chinese Academy of Medical Sciences and Peking Union Medical College. No.1 Shuaifuyuan Wangfujing Dongcheng District, Beijing, China, 100730 email address邓lijun35@hotmail.com Telephone number囚086-010-69151502

\section{References}

1. Yang S, Wu J, Ding C, et al. Epidemiological features of and changes in incidence of infectious diseases in China in the first decade after the SARS outbreak: an observational trend study. Lancet Infect Dis. 2017;17(7):716-725.

2. Quatresooz P, Piérard GE. Skin homing of Treponema pallidum in early syphilis: an immunohistochemical study. Appl Immunohistochem Mol Morphol. 2009;17(1):47-50. 
3. Buffet M, Grange PA, Gerhardt P, et al. Diagnosing Treponema pallidum in secondary syphilis by PCR and immunohistochemistry. J Invest Dermatol. 2007;127(10):2345-2350.

4. Engelkens HJ, ten Kate FJ, Vuzevski VD, van der Sluis JJ, Stolz E. Primary and Secondary Syphilis: A Histopathological Study. International Journal of STD \& AIDS. 1991; 2: 280-284.

5. Martín-Ezquerra G, Fernandez-Casado A, Barco D, Jucglà A, Juanpere-Rodero N, Manresa JM. Treponema pallidum distribution patterns in mucocutaneous lesions of primary and secondary syphilis: an immunohistochemical and ultrastructural study. Hum Pathol. 2009; 40: 624-630.

6. Sangüenza O, Fleet S, Requena L. Histologic findings of cutaneous infections. Adv Dermatol. 2000;16:361-423.

7. Lukehart SA, Baker-Zander SA, Lloyd RM, Sell S. Characterization of lymphocyte responsiveness in early experimental syphilis. II. Nature of cellular infiltration and Treponema pallidum distribution in testicular lesions. J Immunol. 1980;124(1):461-467.

8. Fitzgerald TJ, Miller JN, Sykes JA. Treponema pallidum (Nichols strain) in tissue cultures: cellular attachement, entry and survival. Infect Immun. 1975;11(5):1133-1140.

9. Thomas DD, Navab M, Haake DA, et al. Treponema pallidum invades intercellular junctions of endothelial cell monolayers. Proc Natl Acad Sci USA.1988;85(10):618-624.

10. Engelkens $\mathrm{HJ}$, ten Kate FJ, Judanarso J, et al. The localisation of treponemes and characterisation of the inflammatory infiltrate in skin biopsies from patients with primary or secondary syphilis, or early infectious yaws. Genitourin Med. 1993;69(2):102-107.

11. Bruckner Tuderman L. Biology and pathology of the skin basement membrane zone. Matrix Biol. 1999;18(1):3-4.

12. Cameron CE. Identification of a Treponema pallidum laminin-binding protein. Infect Immun. 2003;71(5):2525-2533.

13. Cameron CE, Brouwer NL, Tisch LM, Kuroiwa JM. Defining the interaction of the Treponema pallidum adhesin Tp0751 with laminin. Infect Immun. 2005;73(11):7485-7494.

14. Cameron CE, Kuroiwa JM, Yamada M, et al. Heterologous expression of the Treponema pallidum laminin-binding adhesin Tp0751 in the culturable spirochete Treponema phagedenis. J Bacteriol. 2008;190(7):2565-2571.

\section{Figures}

A

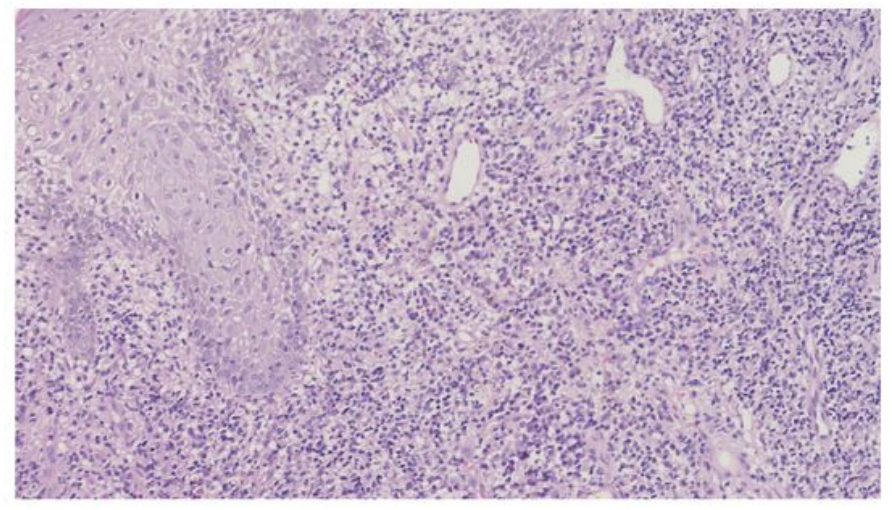

C

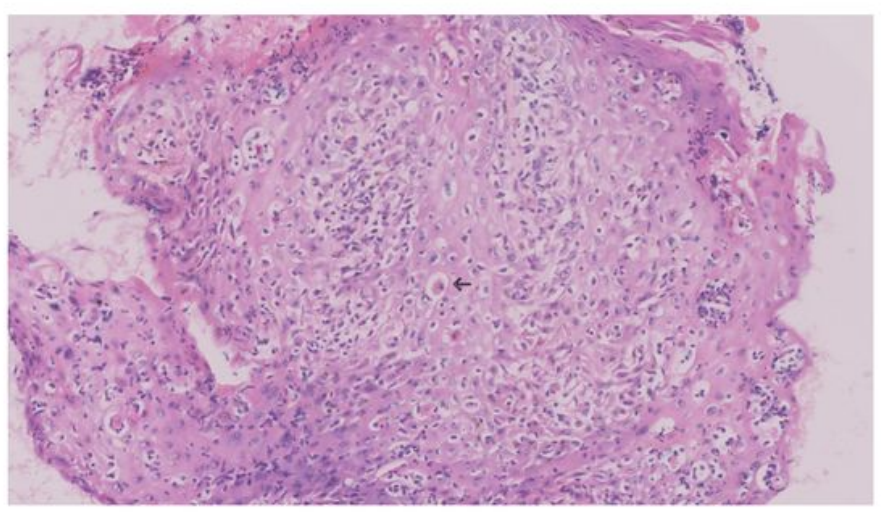

B

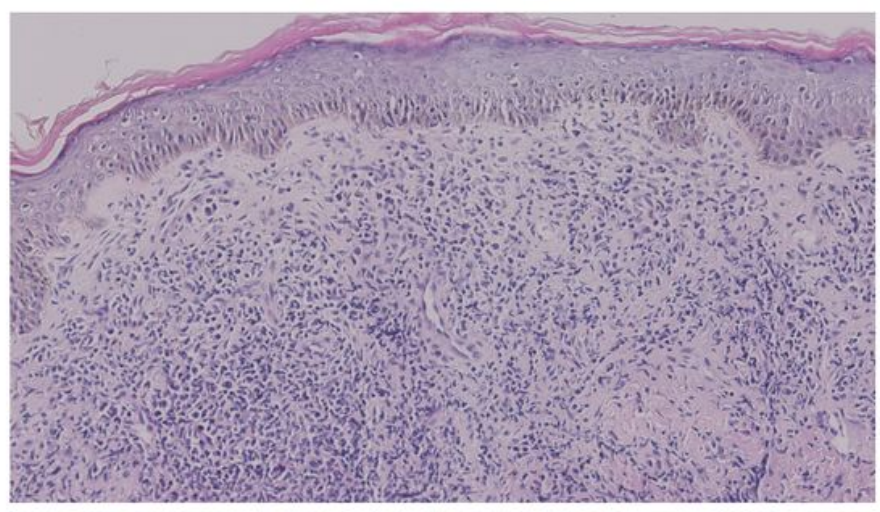

D

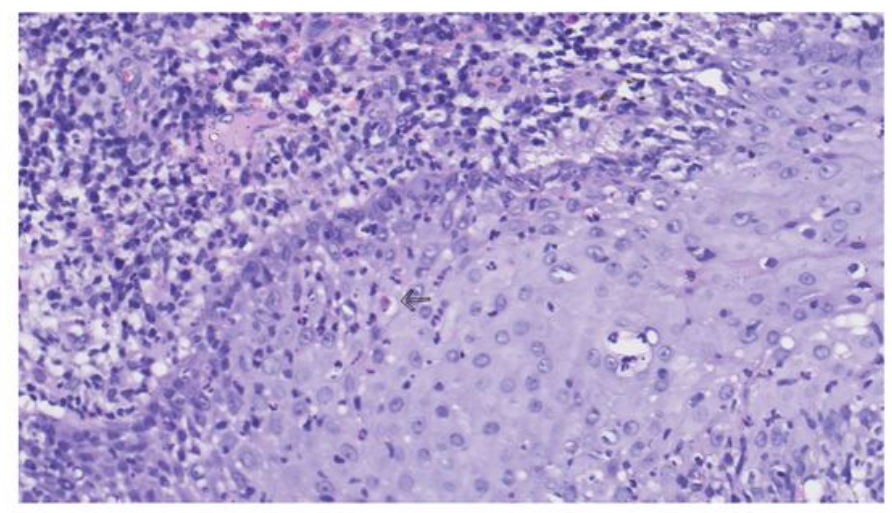


Histological characteristics of primary syphilis. (A) plasma cellular infiltrating in the upper part of dermis (hematoxylin and eosin, magnification $\times 200$ ); (B) dilated vessels and endothelial swelling (hematoxylin and eosin, magnification $\times 200$ ); (C)-(D) keratinocyte apoptosis exhibition scattered bright red cells in epidermis, some of which contain small black pyknotic nuclei (magnification $\times 200$ and $\times 400$ ).

A

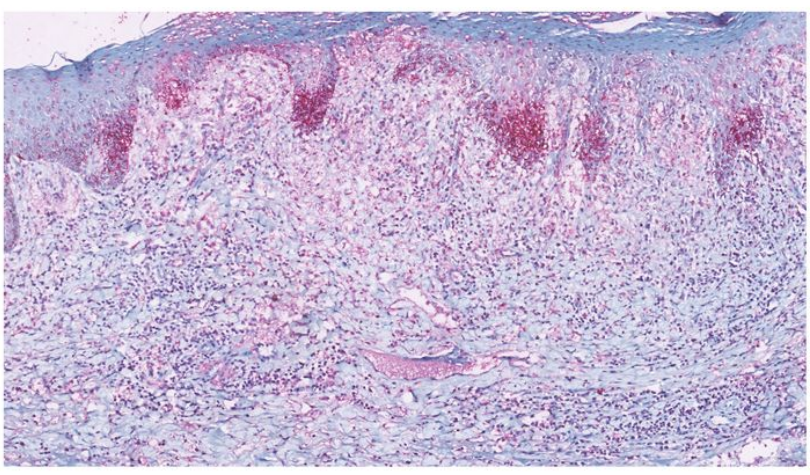

B

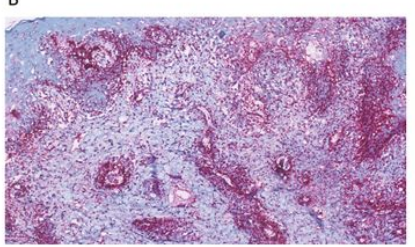

D

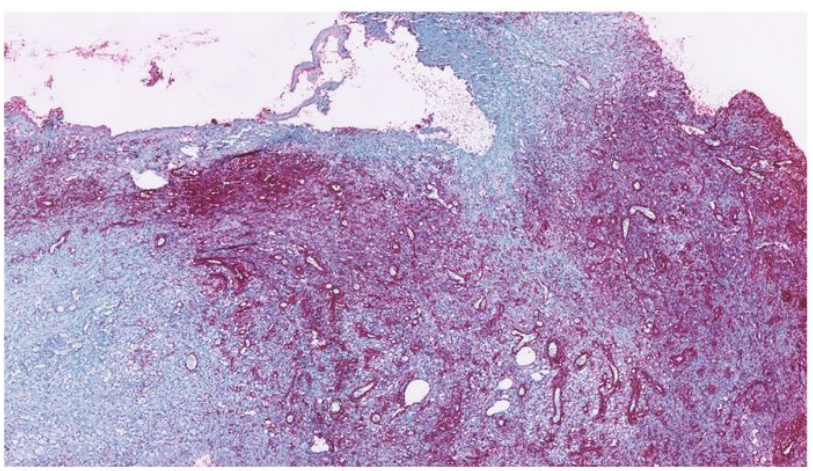

\section{Figure 2}

IHC features of primary syphilis. (A) T. pallidum was found in the lower epidermis (magnification $\times 100)$; (B) T. pallidum in the perivascular area in the dermis area (magnification $\times 200$ ); (C) bacteria quantity of sparse (magnification $\times 150)$; (D) bacteria quantity of dense (magnification $\times 60$ ). 